\title{
Clinicopathological and immunohistochemical evaluation of oesophageal leiomyosarcoma in a dog
}

\author{
Aspectos clínico-patológicos e imuno-histoquímicos de \\ um caso de leiomiossarcoma esofágico canino
}

\begin{abstract}
Renata Cintra Ciccone Alves ${ }^{\mathrm{I}}$ Tatiana Linardi Batista ${ }^{\mathrm{I}}$ Renée Laufer-Amorim ${ }^{\mathrm{II}}$ Fabiana Elias ${ }^{\text {III }}$ Sabryna Gouveia Calazans ${ }^{\text {IV }}$ Carlos Eduardo Fonseca-Alves ${ }^{V}$
\end{abstract}

- NOTE -

\begin{abstract}
Oesophageal leiomyosarcoma is a malignant neoplasm of smooth muscle fibres that is infrequently reported in the literature. Because of the importance of definitive diagnosis and the low incidence of this tumour in dogs, it was reported a case of oesophageal leiomyosarcoma in a dog. A 13-yearold intact male Rottweiler presented regurgitation, hyporexia, and chronic weight loss. After an imaging examination, tumour in the thoracic oesophagus was suspected and a biopsy was sugested for definitive diagnosis. However, the owner did not permit the procedure. Six months after the clinical diagnosis, the patient was brought for evaluation of anorexia, apathy, and severe dyspnoea. Because of the patient's clinical signs and lack of response to emergency treatment, he was euthanized. Upon necropsy, it was identified the neoplastic formation, previously identified in the radiographic examination in the thoracic oesophagus, near the diaphragm. Histopathology revealed a proliferation of mesenchymal cells, and the diagnosis of leiomyosarcoma was confirmed by immunohistochemical examination. Despite the low incidence of oesophageal leiomyosarcoma, it should be included as a differential diagnosis for animals with chronic regurgitation.
\end{abstract}

Key words: diseases of dogs, esophagus, neoplasms, smooth muscle.

\section{RESUMO}

O leiomiossarcoma esofágico é um neoplasma maligno das fibras musculares lisas pouco descrito na literatura e, devido à importância do seu diagnóstico definitivo e à baixa frequência desta neoplasia em cães, relata-se um caso de leiomiossarcoma em localização esofágica. Foi atendido um cão, 13 anos, Rottweiler, com histórico de regurgitação, hiporexia e perda de peso crônica. Após exames complementares de imagem, suspeitou-se de neoplasma localizado em esôfago torácico, no entanto, o proprietário optou por não realizar nenhum exame para o diagnóstico definitivo. Após seis meses do atendimento inicial, o animal retornou com anorexia, apatia e dispneia severa. Devido aos sinais clínicos apresentados e ausência de resposta ao tratamento emergencial instituido, optou-se pela eutanásia. Foi realizada a necropsia e, no esôfago torácico, próximo à região diafragmática, foi possivel identificar a formação neoplásica anteriormente visualizada no exame radiográfico. $O$ exame histopatológico revelou proliferação de células mesenquimais, sugestiva de leiomiossarcoma. O diagnóstico foi confirmado pelo exame imuno-histoquímico. Apesar da baixa frequência do leiomiossarcoma esofágico, animais que apresentam regurgitação crônica devem ser investigados quanto à possibilidade desse diagnóstico.

Palavras-chave: doenças de cães, esôfago, neoplasias, músculo liso.

Leiomyosarcomas are neoplasms that originate from the smooth muscle and are found frequently in the female reproductive tract, especially in the uterus and vagina (OLIAI, et al., 1999). According to WITHROW (2013), oesophageal leiomyosarcomas are extremely rare in veterinary species. Macroscopically, a leiomyosarcoma appears as a circumscribed, uniform mass and may deeply infiltrate the wall of the organ. In some cases, it may cause stenosis and total or partial obstruction of the organ (REDDY et al., 2013). Leiomyosarcoma is histologically characterized by bundles of smooth

\footnotetext{
'Programa de Pós-graduação em Oncologia Veterinária, Instituto Bioethicus, Faculdade de Jaguariúna (FAJ), Jaguariúna, SP, Brasil.

"Faculdade de Medicina Veterinária e Zootecnia (FMVZ), Universidade Estadual Paulista (UNESP), Botucatu, SP, Brasil.

III Universidade Federal da Fronteira Sul (UFFS), Realeza, PR, Brasil.

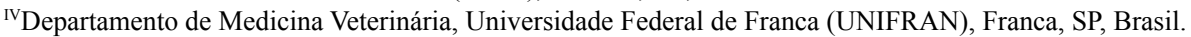

vPrograma de Pós-graduação em Medicina Veterinária, Universidade Estadual Paulista (UNESP), Rua Padre Agra, 70, 18609-020,

Botucatu, SP, Brasil. E-mail: carloseduardofa@hotmail.com. Corresponding author.
} 
muscle fibres arranged in different directions, spindle cells in large quantities, eosinophilic cytoplasm, anisokaryosis, bizarre nuclei, high mitotic index, and dispersed chromatin (SOUZA et al., 2012).

In general, oesophageal neoplasms cause dysphagia and regurgitation because of reduction of the oesophageal lumen (COHEN et al., 2003). Weight loss, oesophageal dilatation proximal to the tumour, cachexia, and aspiration pneumonia are other common clinical signs. Endoscopy, computed tomography, radiography, biopsy, and histopathology can be used to diagnose leiomyosarcoma, but in many cases, immunohistochemistry (IHC) is required for definitive diagnosis (WITHROW, 2013). In IHC, leiomyosarcoma shows immunoreactivity to vimentin, desmin, and alpha actin. The recommended treatment for oesophageal neoplasms is surgical resection (PINTO et al., 2010; WITROW, 2013). Here, it was described the main clinical, histological, and immunohistochemical features of a case of canine oesophageal leiomyosarcoma.

A 13-year-old intact Rottweiler male presented a history of regurgitation, appetite loss, and chronic weight loss. Because of his advanced age and clinical signs, the suspecion was of neoplastic process which was causing the partial oesophageal obstruction. It was obtained a ventrodorsal and left and right lateral radiographs of the cervical and thoracic oesophagus. Because there was a suspecion of the presence of an oesophageal tumour, a radiographic contrast examination was performed using barium sulphate. It was suggested to the owner an endoscopy and biopsy to confirm the diagnosis, but the owner declined.

After further examination, it was recommended feeding the patient a soft diet to avoid episodes of regurgitation and in a semi-upright position to prevent aspiration pneumonia. After 6 months, the patient returned to the care centre with anorexia, apathy, and severe dyspnoea. Emergency procedures were implemented to stabilize the respiratory signs; however, there was no clinical improvement. Because of the patient's intense respiratory distress, he was euthanized and necropsy was performed.

Representative fragments of lung and oesophageal tumour were collected, which were fixed in $10 \%$ buffered formaldehyde solution for 24 hours and then maintained in $70 \%$ alcohol for histological processing. The specimens were embedded in paraffin according to the technique described by FONSECAALVES et al. (2013) and examined with haematoxylineosin staining to establish the definitive diagnosis.

To confirm the histological diagnosis, an immunohistochemical analysis was performed for vimentin (Dako, Carpinteria, CA, USA), cytokeratin (Invitrogen, Carlsbad, CA, USA), desmin (Dako, Carpinteria, CA, USA), MyoD1 (Novocastra, Newcastle-upon Tyne, UK), alpha actin (Dako, Carpinteria, CA, USA), and Ki-67 (Dako, Carpinteria, CA, USA) at dilutions of 1:300, 1:400, 1:200, $1: 100,1: 100$, and 1:50, respectively. Histological sections 3-microns thick were affixed to positively charged slides (CMS-2, Amitel ${ }^{\circledR}$, Brazil), which were maintained for 24 hours at $55^{\circ} \mathrm{C}$. The slides were subsequently deparaffinised with xylene and rinsed in ethanol in a decreasing series of dilutions $(100 \%, 95 \%$, and $85 \%)$. For antigen retrieval, it was used $10 \mathrm{mM}$ citric acid, $\mathrm{pH} 6.0$, in a pressure cooker (Pascal ${ }^{\circledR}$, Dako Cytomation, EUA). Slides were placed in an automatic immunohistochemical processing unit in the Autostainer Classic ${ }^{\circledR}$ platform (Dako, Carpinteria, CA, USA). The evaluation of antibodies was performed as described previously by FonsecaAlves et al. (2013). Smooth muscle fibres from a histologically normal sample were used as an internal positive control for vimentin, desmin, and alpha actin antibodies. Controls used for MyoD1, cytokeratin, and Ki-67 antibodies were striated muscle, prostate epithelium, and mastocytoma samples, respectively. A negative control was performed by omitting the primary antibody, as previously described by FONSECA-ALVES et al. (2013).

Radiographic evaluation of the thoracic oesophagus showed a mass congruent to the cardiac silhouette and cranial to the diaphragm, measuring $7.2 \mathrm{~cm}$ in diameter. There was progression of contrast material through the gastrointestinal tract, ruling out the possibility of total oesophageal obstruction. Another important aspect was the lack of contrast enhancement of the tumour, suggesting an extraluminal mass. Necropsy revealed an off-white, well-circumscribed, uniform mass approximately $10 \mathrm{~cm}$ in diameter in the caudal thoracic oesophagus cranial to the diaphragm, causing partial oesophageal obstruction. In the lung there were areas of brown-towhite haemorrhagic foci, parenchymal hyperaemia, and regions of atelectasis and pulmonary oedema.

Histopathological examination revealed a malignant neoplastic formation composed of spindle cell beams intertwined in various directions, with cells presenting moderate pleomorphism. There were a small number of slit-shaped vessels. The cells had oval nuclei, sometimes blistered with dispersed chromatin, with 3 to 4 mitotic figures in each $400 \times$ field. The histopathological diagnosis was leiomyosarcoma (Figure 1A). 


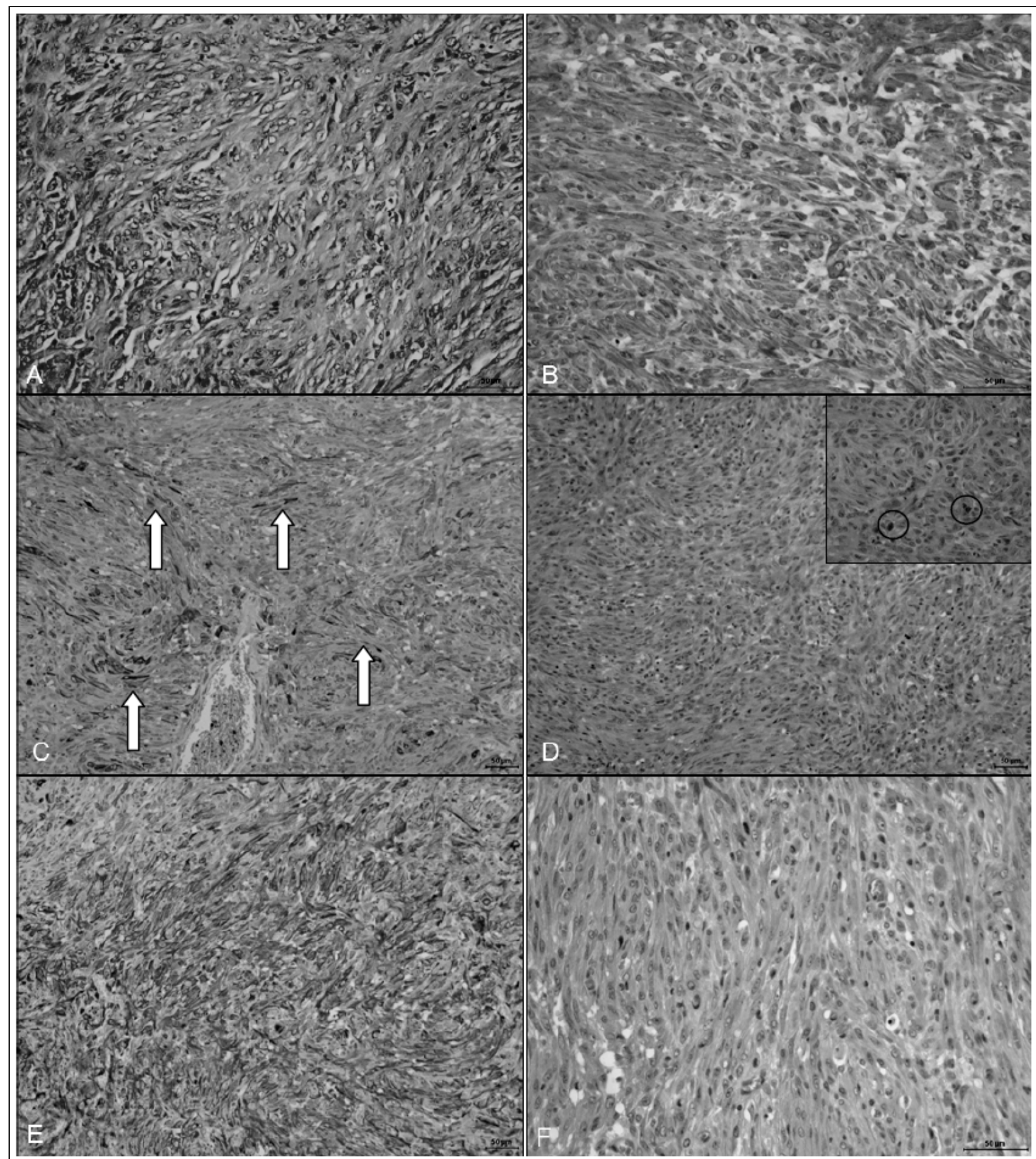

Figure 1 - Histopathological and immunohistochemical evaluation of canine oesophageal leiomyosarcoma. A: Haematoxylin-eosin staining showing a neoplastic formation composed of spindle cells intertwined in various directions. B: Positive diffuse immunohistochemical (IHC) staining for vimentin. C: Positive IHC staining for desmin (arrows). D: Negative IHC staining for Ki-67, with the internal positive control (circle). E: IHC staining for alpha actin, showing diffuse staining in the neoplastic cells. F: Negative IHC staining for MyoD1 protein.

IHC was positive for vimentin (Figure 1B) and desmin (Figure 1C) antibodies and negative for cytokeratin (AE1/AE3), suggesting that the tumour was of muscular origin. The tumour showed low positivity for $\mathrm{Ki}-67$ protein, suggesting a low proliferation index and slow growth (Figure 1D). To make a definitive diagnosis, the tumour was identified as positive for alpha actin (Figure 1D) and negative for MyoD1 protein (Figure 1F).

Oesophageal tumours are uncommon in veterinary medicine, and leiomyosarcomas in this location are considered rare (WITHROW, 2013). The 
mostcommon clinical signs of oesophageal tumours are caused by total or partial obstruction of the oesophagus; therefore, dysphagia, hypersalivation, regurgitation, anorexia, weight loss, and aspiration pneumonia are commonly reported (WITHROW, 2013).

The dog in this report had a mural tumour causing partial obstruction of the oesophagus, chronic weight loss, and regurgitation with secondary aspiration pneumonia. ARNELL et al. (2012) reported four patients with oesophageal neoplasia in the same location and found that all had chronic regurgitation associated with megaoesophagus. This difference may be related to the degree of oesophageal obstruction; $t$ the patient had a partial obstruction, while those reported by SIMO et al. had severe oesophageal obstruction.

While it is possible to establish a diagnosis of leiomyosarcoma on histopathological examination, it is difficult to determine the origin of the tumour using only haematoxylin-eosin stain. Special staining with Masson trichrome differentiates smooth muscle and collagen fibres (REDDY et al., 2013). According to WITHROW (2013), oesophageal sarcomas are most commonly associated with Spirocerca lupi, which is endemic in India and the southern United States. However, no macroscopic or histological evidence of Spirocerca infection was found in the dog in this report.

Squamous cell carcinoma is the most common oesophageal neoplasm and can be distinguished from leiomyosarcoma by histopathology (SOUZA et al., 2012). The most important differential diagnosis for leiomyosarcoma is fibrosarcoma, a malignant mesenchymal neoplasm, which in most cases requires IHC to be definitively distinguished from leiomyosarcoma (RANEN et al., 2004). IHC of the tumour in this report revealed its origin to be smooth muscle, distinguishing it from other possible mesenchymal tumours. The IHC results together with the number of mitotic figures found on histopathology indicated a low degree of malignancy.

WITHROW (2013) reported that low-grade leiomyosarcomas tend to exhibit benign behaviour and grow slowly, as did the tumour described here. Withrow states that survival time in animals with this diagnosis is long because of the low incidence of metastasis. Euthanasia was elected in the present patient because of the partial oesophageal obstruction and reflux with consequent aspiration pneumonia.

Although leiomyosarcoma is uncommon, it should be included in the differential diagnosis for animals with an oesophageal mass. In this case, the tumour did not exhibit aggressive biological behaviour. The clinical signs presented by the patient were associated with chronic regurgitation; dogs with tumours in the oesophagus should receive adequate clinical support to avoid aspiration pneumonia.

\section{ACKNOWLEDGEMENTS}

We would like to thank Fundação de Amparo à Pesquisa do Estado de São Paulo (FAPESP) for their financial support (Portaria CS 14/2004, Grant: 2012/18426-1).

\section{REFERENCES}

ARNELL, K. et al. Persistent regurgitation in four dogs with caudal esophageal neoplasia. Journal of the American Animal Hospital Association, v.49, n.1, p.58-63, 2012. Accessed: <http:// www.ncbi.nlm.nih.gov/pubmed/23148135>. Accessed: Apr. 24, 2014. doi: 10.5326/JAAHA-MS-5826.

COHEN, M. et al. Gastrointestinal leiomyosarcoma in 14 dogs. Journal of Veterinary Internal Medicine, v.17, p.107110, 2003. Available from: <http://www.ncbi.nlm.nih.gov/ pubmed/12564735>. Accessed: Apr. 25, 2014. doi: 10.1111/ j.1939-1676.2003.tb01331.x.

FONSECA-ALVES, et al. Alterations of C-MYC, NKX3. 1, and E-cadherin expression in canine prostate carcinogenesis. Microscopy Research and Technique, v.76, n.12, p.1250-1256, 2013. Available from: $<$ http://www.ncbi.nlm.nih.gov/pubmed/24030851>. Accessed: Jun. 27, 2014. doi: 10.1002/jemt.22292.

OLIAI, B.R. et al. Leiomyosarcoma of the pulmonary veins. American Journal of Surgical Pathology, v.23, p.1082-1088, 1999. Available from: <http://dx.doi.org/10.1155/2012/396319>. Accessed: Apr. 23, 2014. doi: 10.1155/2012/396319.

PINTO, T.M. et al. Esofagectomia torácica parcial no tratamento de leiomioma em esfíncter esofágico inferior de cão. Acta Scientiae Veterinariae, v.38, n.1, p.81-84, 2010. Available from: $<\mathrm{http}: / / \mathrm{www}$. ufrgs.br/actavet/38-1/PUB_880.FINAL.pdf>. Accessed: Apr. 29, 2014.

RANEN, E. et al. Partial esophagectomy with Single layer closure for treatment of esophageal sarcomas in 6 dogs. Veterinary Surgery, v.34, n.4, p.428-434, 2004. Available from: <http:// www.ncbi.nlm.nih.gov/pubmed/15230849>. Accessed: Apr. 25, 2014. doi: 10.1111/j.1532-950X.2004.04062.x.

REDDY, V. et al. A leiomyosarcoma of esophagus: report of two cases. Journal of Case Reports, v.3, n.2, p.436-439, 2013. Available from: <http://www.casereports.in/articles/3/2/A-Leiomyosarcoma-ofEsophagus-Report-of-Two-Cases.html>. Accessed: Apr. 26, 2014.

SOUZA, S.O. et al. Caracterização histopatologicas e imunohistoquimica de neoplasmas mesenquimais da genitália em 43 cadelas. Pesquisa Veterinária Brasileira, v.32, n.12, p.1313-1318, 2012. Available from: <http:/www.scielo.br/ scielo.php?pid=S0100-736X2012001200016\&script $=$ sci arttext $>$. Accessed: Apr. 23, 2014. doi: 10.1590/S0100736 X2012001200016.

WITHROW, S.T. Esophageal cancer. In: WITHROW, S.J. et al. Cancer of the Gastrointestinal Tract. Elsevier: St Louis, 2013. p.399-401. 